NBER WORKING PAPER SERIES

\title{
TRADE WARS: WHAT DO THEY MEAN? WHY ARE THEY HAPPENING NOW? WHAT ARE THE COSTS?
}

\author{
Aaditya Mattoo \\ Robert W. Staiger \\ Working Paper 25762 \\ http://www.nber.org/papers/w25762 \\ NATIONAL BUREAU OF ECONOMIC RESEARCH \\ 1050 Massachusetts Avenue \\ Cambridge, MA 02138 \\ April 2019
}

Thanks to Treb Allen, Emily Blanchard, Chad Bown, Davin Chor, Swati Dhingra, Caroline Freund, Penny Goldberg, Judy Goldstein, Henrik Horn, Doug Irwin, Petros C. Mavroidis, Emanuel Ornelas, Nina Pavcnik, Alan Sykes, Nick Tsivanidis and Ben Zissimos for many helpful comments. All remaining errors are our own. The views expressed in this paper are those of the authors and should not be attributed to the institutions to which they belong, nor to the National Bureau of Economic Research. Research for this paper has been supported in part by the World Bank's Umbrella Facility for Trade.

At least one co-author has disclosed a financial relationship of potential relevance for this research. Further information is available online at http://www.nber.org/papers/w25762.ack

NBER working papers are circulated for discussion and comment purposes. They have not been peer-reviewed or been subject to the review by the NBER Board of Directors that accompanies official NBER publications.

(C) 2019 by Aaditya Mattoo and Robert W. Staiger. All rights reserved. Short sections of text, not to exceed two paragraphs, may be quoted without explicit permission provided that full credit, including $(\odot)$ notice, is given to the source. 
Trade Wars: What do they Mean? Why are they Happening Now? What are the Costs? Aaditya Mattoo and Robert W. Staiger

NBER Working Paper No. 25762

April 2019

JEL No. F02,F13

\begin{abstract}
$\underline{\text { ABSTRACT }}$
How should economists interpret current trade wars and the recent U.S. trade actions that have initiated them? In this paper we offer an interpretation of current U.S. trade actions that is at once more charitable and less forgiving than that typically offered by economic commentators. More charitable, because we argue that it is possible to see a logic to these actions: the United States is initiating a change from "rules-based" to "power-based" tariff bargaining and is selecting countries with which it runs bilateral trade deficits as the most suitable targets of its bargaining tariffs. Less forgiving, because the main costs of these trade tactics cannot be avoided even if they happen to "work" and deliver lower tariffs. Rather, we show that the main costs will arise from the use of the tactics themselves, and from the damage done by those tactics to the rulesbased multilateral trading system and the longer-term interests of the United States and the rest of the world.
\end{abstract}

\author{
Aaditya Mattoo \\ The World Bank \\ amattoo@worldbank.org \\ Robert W. Staiger \\ Department of Economics \\ Dartmouth College \\ 319 Silsby \\ Hanover, NH 03755 \\ and NBER \\ rstaiger@dartmouth.edu
}




\section{Introduction}

How should economists interpret current trade wars and the recent U.S. trade actions that have initiated them? A popular view begins from the premise that tariff increases are inherently undesirable, and condemns the recent U.S. trade actions on the grounds that they will lead directly to higher tariffs, either by design or, if they represent a U.S. bargaining ploy to achieve lower tariffs, because the ploy will fail and the higher "bargaining tariffs" will remain. These trade actions are thought to defy economic logic because they appear to link gains from trade to bilateral trade imbalances and to see trade as a zero-sum game. ${ }^{1}$ A logical consequence of this view, however, is that if these trade wars do lead to negotiated outcomes that result in more open markets, then the tactics will have been proven to be a success for the United States (and possibly for the world).

We put forward an alternative interpretation of current U.S. trade actions, an interpretation that is at once more charitable and less forgiving. More charitable, because we argue that it is possible to see a logic to these actions: according to this logic, the United States is initiating a change from "rules-based" to "power-based" tariff bargaining and is selecting countries with which it runs bilateral trade deficits as the most suitable targets of its bargaining tariffs. Less forgiving, because the main costs of these trade tactics cannot be avoided even if they happen to "work" and deliver lower tariffs. Rather, we show that the main costs will arise from the use of the tactics themselves, and from the damage done by those tactics to the rules-based multilateral trading system and the longer-term interests of the United States and the rest of the world.

\section{Trade Wars and the Rules-Based Multilateral Trading System}

The GATT/WTO rules-based multilateral trading system is built on the pillars of the mostfavored-nation principle (MFN) and reciprocity. MFN embodies the nondiscrimination principle whereby imports of the same product from different countries have the right to face the same (MFN) treatment in a given market. Reciprocity refers to the notion that bargains should be balanced, so that as a result of the agreed tariff liberalization each country can anticipate an increase in the volume of its exports that is roughly equivalent in value to the increase in the

\footnotetext{
${ }^{1}$ Or, in some versions of this view, especially with regard to China, there is a concern that the opportunity to achieve meaningful trade liberalization with the leverage provided by these U.S. initiated trade wars will be squandered in a rush to achieve quick results.
} 
volume of its imports.

These rules constrain the exercise of power; indeed, according to Jackson (1989), this constraint is the very meaning of a rules-based system. MFN dilutes the ability of a powerful country to capture the gains from bargaining down the tariffs of a weaker bargaining partner, because the MFN requirement on the bargaining partner's tariffs ensures in principle that any exporter gains derived from these lower tariffs will be shared as well by third-country exporters. And reciprocity serves to neutralize the exercise of power in tariff bargains, because it establishes balanced terms for the bargain that in principle are not subject to negotiation. ${ }^{2}$

Recent U.S. trade actions can be seen as an attempt to escape from these constraints, and pose an existential threat to the rules-based multilateral trading system. The nature of this threat is well-reflected in the following statement by Wilbur Ross, U.S. Secretary of Commerce, describing the current Administration's vision of the ideal global trading system:

An ideal global trading system would facilitate adoption of the lowest possible level of tariffs. In this ideal system, countries with the lowest tariffs would apply reciprocal tariffs to those with the highest and then automatically lower that reciprocal tariff as the other country lowers theirs. This leveling technique could be applied product by product or across the board on an aggregated basis. Such a modification would motivate high-tariff countries to reduce their tariffs on imports. (WSJ, May 25, 2017)

The global trading system described by Secretary Ross would abandon MFN and would introduce a notion of reciprocity - reciprocity in tariff levels rather than in negotiated tariff changes - that is unprecedented in the GATT/WTO system. In effect, it would repeal the rules-based multilateral trading system and replace it with something more like a power-based system where countries are free to bargain in a way that is not constrained by any particular set of agreed-upon rules of behavior. ${ }^{3}$

\footnotetext{
${ }^{2}$ And when applied together and strictly enforced, MFN and reciprocity can in principle induce bargaining outcomes that are independent of the relative bargaining power of the negotiating parties (Bagwell and Staiger, 1999). Curzon (1966) describes the important roles played by MFN and reciprocity in the early rounds of GATT tariff bargaining, while Bagwell, Staiger and Yurukoglu (2018, 2019) provide related empirical evidence.

${ }^{3}$ Eventually, rather than a power-based system, it might be possible to think of the reciprocal tariff "leveling technique" described by Secretary Ross as itself taking the form of a proposal for a new rules-based system. But the only manifestation of this technique to date is in the form of U.S. bargaining tariffs in the context of the current trade wars, which themselves are being used for power-based bargaining (i.e., bargaining with tariff threats that are not constrained by existing U.S. tariff commitments).
} 


\section{Recent U.S. Trade Actions as Bargaining Tariffs}

To interpret recent U.S. trade actions, we adopt the premise that the recent U.S. tariff increases are bargaining tariffs along the lines described by Secretary Ross. That is, we assume that these tariffs were raised above the levels to which the United States has committed in existing trade agreements with the goal of inducing U.S. trading partners to reduce their tariffs, and in this way to use U.S. bargaining power to rebalance the terms of existing trade agreements in favor of the United States.

The need to employ U.S. bargaining tariffs in order to induce U.S. trading partners to reduce their tariffs is not self-evident. After all, bargaining tariffs were not needed to bring bargaining partners to the table over the past 70 years of successful GATT/WTO multilateral trade liberalization. Over that period, the major industrialized countries came together repeatedly and shared in the positive-sum gains from each round of bargaining as reciprocal trade liberalization moved them ever closer to the international efficiency frontier. What is different now? We suggest two answers to this question.

A first answer applies to the use of U.S. bargaining tariffs against industrialized countries such as Japan and the EU, where reciprocal MFN tariff bargaining (and preferential tariff bargaining for countries such as Canada, Mexico and the Republic of Korea) has largely run its course. Here the threat of bargaining tariffs is needed to spur negotiations, because most of the positive-sum gains from reciprocal tariff liberalization between these countries have already been achieved by earlier trade agreements. This makes any further tariff negotiation beyond the tariff commitments already made in those agreements at best a reallocation among countries of the existing spoils from globalization - that is, a movement along the international efficiency frontier - and hence, in effect, a zero-sum game. ${ }^{4}$ And the threat of bargaining tariffs is needed to induce a (zero-sum) reallocation of these spoils.

This is illustrated for a 2-country world in Figure 1, which depicts the domestic country's tariff $t$ on the vertical axis and the foreign country's tariff $t^{*}$ on the horizontal axis. In the absence of a trade agreement, we can think of the two countries setting noncooperative tariffs

\footnotetext{
${ }^{4}$ Here and throughout we follow the literature on the economics of trade agreements and define efficiency as judged by the preferences of governments (which may reflect the use of tariffs for revenue needs or income distribution concerns; see, for example, Bagwell, Bown and Staiger, 2016), and hence the existence of tariffs per se would not be evidence of inefficiency. While by this metric positive sum gains could likely still be obtained from further trade liberalization among industrialized countries, these gains are likely to be small compared to what was possible in the early years of negotiated liberalization of trade in manufactures.
} 
$t^{N}$ and $t^{* N}$ given by the Nash point in Figure 1 labeled $N$, where the domestic country Nash iso-welfare contour (pictured in blue and labeled $W^{N}$ ) is vertical and the foreign country Nash iso-welfare contour (pictured in red and labeled $W^{* N}$ ) is horizontal. The downward lens created by the two Nash iso-welfare contours reflects the possibility of positive-sum gains from reciprocal tariff liberalization, as both countries gain relative to Nash when they agree to tariff reductions that move them into the lens. Also depicted in Figure 1 is the international efficiency frontier, defined by the locus of points where the iso-welfare contours of the two countries are tangent, labeled as $E E$ : starting from a point on $E E$ there is by definition no lens (up or down), hence no positive-sum gains are possible from this starting point. Finally, the contract curve is the bold portion of $E E$ that lies inside the lens created by the two Nash iso-welfare contours.

Suppose in a first round of tariff negotiation the two countries were to agree to the tariffs $t_{0}$ and $t_{0}^{*}$ moving from the Nash point $N$ to the initial agreement point $A_{0}$ in Figure 1 . Beginning from $A_{0}$ where the domestic country has already committed to the tariff $t_{0}$ and the foreign country has already committed to the tariff $t_{0}^{*}$, we may now ask whether either country would need to threaten the other with a bargaining tariff - that is, a tariff higher than that implied by its existing commitment - in order to bring its bargaining partner to the table again. Because we have assumed that their initial agreement $A_{0}$ lies above the efficiency frontier $E E$, the possibility of further positive-sum gains exist at $A_{0}$ as reflected by the downward lens created by the two iso-welfare contours passing through $A_{0}$, and so bargaining tariffs are not required: with their existing tariff commitments $t_{0}$ and $t_{0}^{*}$ as their threat points, each country could gain from a bargain that involved further reciprocal tariff cuts, and we illustrate the possibility that in this later negotiation they agree to the tariffs $t_{1}$ and $t_{1}^{*}$ and reach a point like $A_{1}$ in Figure 1 that rests on the efficiency frontier. We can think of the movements from the Nash point to the initial agreement point $A_{0}$ and from $A_{0}$ to the efficient point $A_{1}$ as representing in a stylized way the GATT/WTO process of repeated rounds of reciprocal tariff liberalization between industrialized countries that transpired over the past 70 years. ${ }^{5}$

But now, having reached the point $A_{1}$ on the efficiency frontier, things are different. As we have observed, beginning from a point like $A_{1}$ there is no lens and hence no positive-sum gains are possible from this starting point. This means that if, say, the domestic country would like to engineer a tariff bargain that moves the two countries from $A_{1}$ to a point such as $A_{2}$ in Figure

\footnotetext{
${ }^{5}$ The question of why the GATT/WTO process of liberalization took the form of repeated rounds over many decades rather than a single negotiation is the focus of a literature on gradual trade liberalization (see, for example, Staiger, 1995, Devereux, 1997, Furusawa and Lai, 1999, and Bond and Park, 2002).
} 
1 that is more favorable to the domestic country (and also efficient), the domestic country must resort to bargaining tariffs. For example, as Figure 1 illustrates, in the case where the foreign country is committed to a tariff of $t_{1}^{*}$ or lower, the domestic country must be able to impose a bargaining tariff of $t^{B}$ or higher in order to induce its desired (zero-sum) reallocation of the spoils from globalization.

A second answer applies to large developing countries such as the BRICS (Brazil, the Russian Federation, India, China and South Africa) that were mostly inactive during earlier episodes of reciprocal liberalization but have now grown to a size where their markets and protection matters. This has created a "latecomer's" problem: efficiency gains from reciprocal tariff liberalization are likely available for these countries, but industrialized countries that have already engaged in reciprocal tariff liberalization with each other and now have low levels of protection have little left to offer these countries in reciprocal tariff bargaining. Here again, given existing U.S. tariff commitments, the threat of bargaining tariffs is needed to induce these countries to reduce their tariffs. ${ }^{6}$ This can also be understood heuristically with the aid of Figure 1 , by imagining that in a first phase the domestic and foreign country comprise essentially the entire world trading system and bargain to the point $A_{1}$ on the efficiency frontier as described above. But then, in a second phase, a second large foreign country enters the world trading system, with its tariff unconstrained by previous commitments. In terms of Figure 1, it is then as if in this second phase, by their previous negotiations the domestic and original foreign country have their tariffs constrained at the level now represented by $t_{1}$ while the new foreign country is free to set its best-response tariff $t^{* R}$ (not pictured) where its iso-welfare contour is tangent to the horizontal line through $t_{1}$. As Figure 1 suggests, if the new foreign country constitutes a sufficiently large part of the world trading system, the domestic and original foreign country must resort to bargaining tariffs if they wish to engage in tariff negotiations with the new foreign country that can lead to bargaining outcomes on the contract curve (i.e., that leave them better off than at their unconstrained Nash point with the new foreign country). ${ }^{7}$

\footnotetext{
${ }^{6}$ Bagwell and Staiger (2014) define the latecomer's problem and describe a possible approach to this problem which would employ GATT Article XXVIII renegotiations in the context of the Doha Round to achieve bargaining tariffs against latecomers while maintaining MFN and reciprocity (see also note 17). The difference is that their approach to the latecomer's problem would stay within the rules-based system and hence not allow the exercise of U.S. bargaining power. Beyond the latecomer's problem, there are also unique trade policy issues raised by the nature of China's economy which echo concerns raised in the 1980's about Japan's unique economic system.

${ }^{7}$ If we think of this new foreign country as representing in a heuristic way the arrival of the BRICS, then our assumption that their tariff levels are unconstrained by previous GATT/WTO commitments is to the first
} 
But why choose countries with which the United States runs large bilateral trade deficits to be the targets of its bargaining tariffs? ${ }^{8}$ For U.S. bargaining tariffs to succeed in rebalancing the terms of existing trade agreements in favor of the United States, it must be the case that U.S. bargaining partners cannot muster as strong a threat of their own. Bilateral trade imbalances can serve as a possible metric for identifying potential bargaining partners where U.S. bargaining tariffs could have the intended effect.

Consider a simple thought experiment where three symmetric countries are engaged in a triangular "clockwise" trade pattern, with country A exporting a large volume of some good to country B, country B exporting a large volume of some good to country C, and country C exporting a large volume of some good to country A, and where only an insignificant amount of "counterclockwise" trade goes the other way around the triangle. Then country A runs a bilateral trade surplus with country B, country B runs a bilateral trade surplus with country $\mathrm{C}$, and country $\mathrm{C}$ runs a bilateral trade surplus with country A.

Let us assume that each country has access to import tariffs but no export policies, and that in the initial situation the three countries have cooperated and signed a free trade agreement. Country $\mathrm{C}$ receives large gains from the tariff commitments made by $\mathrm{A}$ not to impose a tariff on the large clockwise imports from $\mathrm{C}$, and gives virtually nothing back to A with the tariff commitments it makes not to impose a tariff on the insignificant counterclockwise imports from A. By choosing country $\mathrm{C}$ as the target of its bargaining tariff when attempting to renegotiate the existing trade agreement, country A can exploit the asymmetric bargaining position provided by its large bilateral trade deficit with country C. Its threat to impose noncooperative tariffs on country C's imports could coerce country C into giving up virtually all the joint gains from their bilateral tariff commitments, a bargaining feat that country A could not replicate if it tried the same tactic on country B (with whom country A runs a large trade surplus).

The upshot, then, is that rather than interpreting recent U.S. trade actions as reflecting the view that (i) trade is a zero-sum game and that (ii) bilateral trade deficits signify trading partners with whom the United States loses from trade, we can make progress in interpreting

order a reasonable approximation except possibly for the case of China, which did agree to meaningful tariff commitments as part of its 2001 accession to the WTO. But even for China, this assumption is arguably not unreasonable, as it is unlikely that the tariff concessions that China was asked to make as its initial terms of entry into the WTO fully reflected anticipation of its rapid post-entry growth in the world trading system.

${ }^{8}$ We take this feature of recent U.S. trade actions as a given, but there is of course the question of whether these trade actions do in fact threaten bargaining tariffs consistently against countries with which the United States runs large bilateral deficits - or whether instead it is only that the United States consistently claims that the countries that it threatens are running large bilateral trade surpluses with the United States. 
these actions if we see them slightly differently, as arising from a view that (i') negotiating further trade agreements is a zero-sum game (or subject to the latecomer's problem) and that (ii') bilateral trade deficits signify trading partners with whom U.S. bargaining tariffs create the strongest threat point.

\section{Hegemonic Transition and the Rules-Based Multilateral System}

If one accepts that there is an underlying meaning to recent U.S. trade actions, then this raises a further question: Why are these trade actions and the trade wars that they have initiated happening now?

In 1947, the United States was the unquestioned hegemon of the world economy and played a central role in the creation of the GATT (Irwin, Mavroidis and Sykes, 2011). Below we describe how it can be in the enlightened self-interest of a sufficiently dominant hegemon to provide support for a rules-based system that limits its ability to exercise power. But the flip side is also true: as the dominance of the hegemon wanes, this support can erode, precipitating the collapse of the rules-based system until another sufficiently dominant hegemon rises to take its place. From this perspective, the decline in U.S. support for the WTO - which arguably began well before the current administration - could reflect in part its declining hegemonic status. ${ }^{9}$

The potential impact of the decline and ascent of hegemons on the world trading system is illustrated in a stylized way in Figure 2, which depicts a hypothetical hegemonic transition between two countries, which for purposes of illustrating the broad ideas we refer to as the United States and China. With time on the horizontal axis running from left to right, Figure 2 shows the payoffs of the United States and China under rules-based and power-based regimes over four phases, as the relative power positions of the two countries evolve with faster relative growth in China.

To understand the equilibrium in Phase I under U.S. hegemony (and by symmetry in Phase IV, China Hegemony), recall from Section 2 that a commitment to MFN and reciprocity dilutes the exercise of power. This commitment clearly benefits the weak, but paradoxically it can also be valuable for powerful countries, precisely when they are at their most powerful. This is

\footnotetext{
${ }^{9}$ In fact, one could argue that evidence of power-based bargaining could already be seen in the strategy used by the major players in the GATT Uruguay Round to deal with "holdouts" in creating the WTO, namely, withdrawing from GATT and acceding to the newly formed WTO (see Posner and Sykes, 2014).
} 
because as hegemons, such countries face the greatest difficulty committing not to exploit the weak ex post, once the bargaining has begun and the latter are trapped by relationship-specific sunk costs or become vulnerable to exclusion from trade deals between the hegemon and other weak countries. And in the absence of this commitment, the weak can credibly stay away from the bargaining table, depriving the strong of any gains from trade bargaining. By providing a commitment technology to restrain the strong, the rules-based system encourages participation of a broader set of countries in the global economy, to the benefit of both the most powerful countries and the weak countries. ${ }^{10}$

This last feature is puzzling. After all, could not even the weakest of countries expect to gain some value from participating in power-based trade negotiations with a powerful country? And if so, why then would a hegemon need to commit to rules that constrain its bargaining power in order to ensure participation of the weak? The answer to these questions lies in the distinction between ex-ante and ex-post threat points, and the insight that bargaining outcomes hinge on ex-post threat points while participation decisions depend on ex-ante threat points as well.

The ex-post threat point is what a country can get by walking away from an ongoing bargain and entering into a noncooperative Nash relationship with its trading partner(s). A hegemon engaged in power-based bargaining with a weak country can likely strike a deal that pushes that country very close to its ex-post threat point. The ex-ante threat point is what the country can get in the noncooperative Nash equilibrium if the plans for a bargain never get off the ground. If a country's participation in an ongoing bargain worsens its threat point, because for example it becomes trapped by relationship-specific sunk costs that are incurred while the bargaining is ongoing in anticipation of a final agreement, then the country's ex-post threat point will be worse than its ex-ante threat point. And in this case, a weak country, expecting to receive very close to its ex-post threat point from a power-based bargain with a sufficiently dominant hegemon, could rationally anticipate that it will be hurt relative to its ex-ante threat point if it agrees to participate in power-based bargaining with the hegemon, and it could on this basis

\footnotetext{
${ }^{10}$ See Bagwell and Staiger (1999), Bagwell, Staiger and Yurukoglu (2018), Goldstein and Gowa (2002) and McLaren (1997). Bagwell and Staiger and Goldstein and Gowa describe the participation benefits of a rulesbased system in the context of McLaren's anticipatory sunk-cost model of trade negotiations (see Winters, 1984, and Freund and McLaren, 1999, for evidence in support of anticipatory sunk investments in the context of trade negotiations). Bagwell, Staiger and Yurukoglu find that the threat point of weaker countries is substantially impacted by multilateral bargaining externalities and worsens if those bargains do not abide by MFN.
} 
rationally decide against participation. ${ }^{11}$

The implications of these considerations are illustrated in Figure 2. In the U.S. Hegemony phase, the countries would be stuck in a noncooperative Nash equilibrium under a power-based regime, with the weak country (China) refusing to participate in power-based negotiations for the reasons discussed above. This is reflected in Figure 2 by the fact that in the U.S. Hegemony phase the payoff to China under power-based bargaining (dashed red line), while above China's ex post once-the-bargaining-has-begun Nash payoff (dash-dotted thin red line), is below its ex ante Nash payoff (thin red line), that is, below the payoff China could expect if it simply stayed away from the bargaining table and never let the bargaining process get off the ground; and so the payoffs for the two countries under a power-based regime would be their (ex ante) Nash payoffs (thin blue line for the United States, thin red line for China). Figure 2 also shows the rules-based payoff for each country, which is independent of relative power positions and depicted above the Nash payoffs, reflecting the positive-sum gains from bargaining. The rulesbased payoff is the same across all phases of the hegemonic transition (and hence a horizontal line), and for simplicity we depict the rules-based payoffs of the United States and China as the same (green line). In the U.S. Dominance phase, the payoff to China under power-based bargaining (thick red line) is now above China's ex ante Nash payoff (thin red line), and so China is willing to participate in power-based bargaining with the United States; and initially, at the border between the U.S. Hegemony and U.S. Dominance phases, the United States payoff (thick blue line) captures all the gains from the bargain relative to the ex ante Nash payoffs. The power-based payoffs of the two countries converge at the border between U.S. Dominance and China Dominance where the two countries are equally powerful, and then the payoffs of the United States and China play mirror image roles, as we move through the China Dominance phase and finally to the China Hegemony phase. ${ }^{12}$

\footnotetext{
${ }^{11}$ In the case of multilateral bargaining externalities of the kind emphasized by Bagwell, Staiger and Yurukoglu (2018), weaker countries would need to coordinate their decision not to participate in power-based trade bargaining with a hegemon: in the absence of such coordination, a single weak country acting alone and taking the participation decisions of all other countries as given would then take the ex-ante threat point as given and (in the absence of other reasons for differences between ex-ante and ex-post threat points such as sunk investments) also as its ex-post threat point, and would then always choose to participate.

${ }^{12}$ That the power-based payoffs of the two countries converge to their rules-based payoffs at the border between U.S. Dominance and China Dominance in Figure 2 reflects an assumption that power-based and rules-based bargaining are equally efficient. If, as we argue in section 5 is likely to be the case, rules-based bargaining is more efficient than power-based bargaining, then at the border between U.S. Dominance and China Dominance in Figure 2 the power-based payoffs of the two countries - and hence the intersection of the thick blue and red lines - would lie below the rules based payoffs, introducing an interval of rules-based regime around the symmetric power case. We return to consider this case in section 5 .
} 
Under the assumption that the relatively more powerful country chooses whether it will subject itself to rules that constrain its power, the thick solid lines in Figure 2 display the equilibrium payoffs of each country under the equilibrium regime choices in each phase. ${ }^{13}$ The equilibrium regime choice for each phase is determined by picking the regime, rules-based or power-based, that delivers the highest payoff for the relatively more powerful country in that phase. In equilibrium, under both regimes bargaining will occur, and countries will reach the international efficiency frontier; the difference across regimes is where on the frontier countries will end up.

In the U.S. Hegemony phase, the United States chooses to tie its hands in a rules-based regime. During this phase, the weak country (China) can credibly threaten not to bargain with the United States in the absence of rules, and hence the United States must rely on rules to induce China's participation. In the U.S. Dominance phase, the United States does better in a power-based regime than a rules-based regime and chooses to withdraw support from the rulesbased regime and escape from the constraints of the rules-based system that it once created. During this phase, China would like to threaten not to bargain with the United States in the absence of rules, but unlike in the U.S. Hegemony phase this threat is not credible, and hence the United States does not need to rely on rules to induce China's participation. The remaining phases are then mirror images of the first two phases just described. In the China Dominance phase, China now does better in a power-based regime than a rules-based regime and chooses not to support a rules-based regime. And finally, in the China Hegemony phase, China chooses to tie its hands in a rules-based regime.

The duration of the phases in Figure 2 is not exogenously determined but will depend on the policy choices of the countries to the extent that those policy choices determine their relative growth rates. China clearly has an incentive to accelerate the transition from U.S. Dominance to China Dominance, suggestive of the pro-active industrial policies adopted under the China 2025 program. In contrast, the United States has an incentive to prevent or at least delay the transition, suggesting an added rationale for the trade and investment restrictions it is imposing on China. In any case, to the extent that the waning U.S. support for the rules-based multilateral system can be attributed to changing relative dominance, it is not likely to be a

\footnotetext{
${ }^{13}$ Our assumption that the relatively more powerful country determines the regime can be formalized in a 2 -stage game in which, in stage 1, the more powerful country decides whether or not to commit to rules for bargaining, and then in stage 2 , the more powerful country invites the weaker country to bargain, an invitation that the weaker country can either accept or decline.
} 
temporary phenomenon that will be reversed at the end of the current administration.

\section{Losing the Benefits of the Rules-Based System}

Sections 3 and 4 have provided a partial rationale for recent U.S. trade actions. However, this rationale relies on what is essentially a myopic logic. Apart from MFN and reciprocity, reputational considerations and basic norms of cooperation are also important features of the rules-based system. The recent U.S. trade actions have put all these features at risk, and their destruction could cause lasting and irreversible damage to the existing rules-based system. These U.S. trade actions could be short-sighted even from a purely U.S. perspective once these additional dimensions are considered.

Consider, for example, the thought experiment in Section 3. There we focused on the possibility that country A would break from the norms under an existing agreement and use bargaining tariffs against its "weaker" trading partner, i.e. the trading partner with which it runs a bilateral trade deficit. But once country A does this, it may become acceptable for its bargaining partners to resort to the same strategy: other countries' efforts could shift from seeking exemptions from U.S. actions to imitating these actions. And if this happens, any initial bargaining advantage that country A enjoys from being the first to exploit this strategy would quickly erode. In fact, the ability to maintain any cooperation at all might be put in jeopardy because of the multilateral enforcement issues that arise in this setting. ${ }^{14}$

The hegemonic transition in Section 4 assumed that China's optimal actions when it achieves hegemon status are completely independent of U.S. actions today. But the U.S. breaking of rules today could damage the reputation of the multilateral trading system and make it more difficult for a future hegemon to reintroduce a commitment mechanism tomorrow. The result could be a period of China Hegemony without the benefit of an effective rules-based system, which would be costly for the United States, as shown in Figure 2.

Other costs are likely to arise from undermining the central WTO rules as well. MFN and reciprocity can mitigate strategic behavior and the bargaining frictions that can accompany such behavior, and in this way can help to speed up the bargaining process and avoid inefficient bargaining outcomes. In this regard, Curzon (1966, p 74) comments on the striking lack of strategic behavior in early GATT negotiating rounds, noting that the presumption of balance

\footnotetext{
${ }^{14}$ See Maggi (1999).
} 
in the terms of the bargain implied by reciprocity creates "a much better negotiating climate than the opposite trend which was a feature of the classical bilateral negotiations. Then, everyone put forward very low offers with the intention of increasing gradually if the bargaining proved profitable. A country never knew, however, when it had reached the maximum its partner was willing to concede." And according to an early GATT report (ICITO, 1949, p. 10), combining reciprocity and MFN together in a multilateral negotiating round "produced a technique whereby governments, in determining the concessions they are prepared to offer, are able to take into account the indirect benefits they may expect to gain as a result of simultaneous negotiations between other countries, and whereby world tariffs may be scaled down within a remarkably short time." 15 By contrast, there is ample historical evidence that the use of bargaining tariffs leads to outcomes far away from those that might be considered desirable or efficient: for example, Wallace (1933, p 630) provides an account of the disappointing European experience with bargaining tariffs during the second half of the 19 th century. ${ }^{16}$

The evidence that WTO rules enhance the efficiency of tariff bargaining relative to what might occur absent these rules also has implications for the hegemonic transition described in Figure 2, because Figure 2 reflects an assumption that power-based bargaining and rules-based bargaining are equally efficient. In Figure 3 we depict the implications of the relative efficiency of rules-based bargaining for our hegemonic transition analysis. Now the power-based payoffs of the two countries converge to a point below their rules-based payoffs at the border between U.S. Dominance and China Dominance, reflecting the inefficiency of power-based relative to rules-based bargaining and the associated loss of joint surplus under the former. This has two implications. First, it extends the U.S. Hegemony and China Hegemony phases under which the rules-based system is the equilibrium regime choice. And second, it introduces an additional interval of time in the U.S. Dominance and China Dominance phases where the two countries are relatively symmetric during which the rules-based system is again the equilibrium regime choice. Together these two implications shrink the periods of time during which a power-based regime might look attractive to a dominant country. The upshot is that the more efficient is

\footnotetext{
${ }^{15}$ See Schwartz and Sykes (1997) and Bagwell and Staiger (2005, 2010, 2016, 2018a) for theoretical treatments of these benefits from reciprocity and MFN, and see Bagwell, Staiger and Yurukoglu $(2018,2019)$ for related empirical evidence.

${ }^{16}$ GATT/WTO rules can also be seen to facilitate a "shallow" approach to liberalization that allows governments to target their commitments to the source of the international inefficiency (insufficient market access) and that therefore minimizes conflicts with notions of national sovereignty (see Bagwell and Staiger, 2001, 2018b). To the extent that such conflicts are undesirable when they are avoidable, this points to a further cost from undermining the central WTO rules.
} 
rules-based bargaining relative to power-based bargaining, the more likely it is that U.S. trade actions that undermine the rules-based system will ultimately be viewed as short-sighted.

\section{Conclusion: The Enlightened Self-Interest of a Declining Hegemon}

The increasing symmetry in the size of countries and asymmetry in the protection of major trading partners may be prompting the United States to resort to bargaining tariffs. At the same time, the declining relative importance of the United States in the world economy may have reduced its need to reassure trading partners by committing to rule-based trade negotiations, and increased its incentive to delay hegemonic transition.

While these considerations provide a possible rationale for recent U.S. trade actions, a less myopic view of their consequences would dictate greater U.S. restraint. First, if other countries follow the U.S. example, and take similar actions, then the United States will likely lose any benefits from its actions, and multilateral trade cooperation itself could end up being the casualty. Second, to the extent that U.S. actions inflict permanent damage to the rules-based system, the United States may ultimately suffer from the absence of restraints on the actions of a future hegemon.

There is also a further consideration if U.S. trade actions are, or in the future might be, motivated not just by the international bargaining power considerations we have emphasized but by domestic concerns. For example, the United States might wish to alleviate adjustment costs or distributional effects by limiting trade, temporarily or durably, in certain import competing sectors to levels below those implied by its existing tariff commitments. The GATT/WTO was designed to accommodate these types of pressures without the rules-based system being undermined. Members can take short-term safeguard action (under Article XIX of GATT 1994) or make long-term changes in existing commitments through Article XXVIII renegotiations which are built on the threat point of reciprocal withdrawal of previously negotiated tariff commitments. If it so desired, the United States could enter into Article XXVIII renegotiations with its impacted trading partners to raise its tariffs on selected products or industries, with the knowledge that if the negotiations broke down it would be allowed to raise those tariffs anyway, and its trading partners would be allowed to respond by raising their tariffs in a reciprocal fashion. ${ }^{17}$ The provision of a framework that allows adjustments of tariff commitments to

\footnotetext{
${ }^{17}$ Article XXVIII renegotiations could also in principle be used, in combination with a further round of multilateral tariff negotiation, to reorient the existing pattern of negotiated tariff commitments, away from
} 
proceed in an orderly manner in the face of changing circumstances is another strength of the existing rules-based system that current U.S. trade actions are placing at risk.

Finally, according to Figure 2, the payoff to the United States from power-based trade bargaining in the phase labeled China Dominance is smaller than the payoff from rules-based trade bargaining in the phase labeled China Hegemony. This raises a counter-intuitive and provocative possibility: if the rise of China cannot be avoided, then the United States might eventually be better off working to accelerate this rise, through the phase labeled China Dominance in Figure 2 and to the phase labeled China Hegemony. Of course, whether China is itself on an inexorable path through these phases is a major unknown, and there are important military and geopolitical concerns that go beyond the purely economic issues that we have considered here. But the broad themes that we have outlined do raise at least the possibility that the enlightened course of action for a declining hegemon could be to evade the Thucydides trap by facilitating rather than resisting a new hegemony.

\section{References}

Bagwell, Kyle, Bown, Chad, and Robert W. Staiger (2016), "Is the WTO Passe?" Journal of Economic Literature 54(4): 1125-1231.

Bagwell, Kyle, and Robert W. Stagier (1999), "An Economic Theory of GATT," American Economic Review 89(1): 215-248.

Bagwell, Kyle, and Robert W. Stagier (2001), "Domestic Policies, National Sovereignty and International Economic Institutions," Quarterly Journal of Economics 116(2): 519-562.

Bagwell, Kyle and Robert W. Staiger (2002), The Economics of the World Trading System, Cambridge, MA: The MIT Press.

Bagwell, Kyle and Robert W. Staiger (2005), "Multilateral Trade Negotiations, Bilateral Opportunism and the Rules of GATT/WTO," Journal of International Economics 67(2): 268-94.

Bagwell, Kyle and Robert W. Staiger (2010), "Backward Stealing and Forward Manipulation in the WTO," Journal of International Economics, 82(1): 49-62.

Bagwell, Kyle, and Robert W. Stagier (2014), "Can the Doha Round be a Development Round? Setting a Place at the Table," in Robert C. Feenstra and Alan M. Taylor (eds.), Globalization in an Age of Crisis: Multilateral Economic Cooperation in the Twenty-First Century, University of Chicago Press, January.

the pattern of tariff commitments that emerged under reciprocity from the historically dominant North-North tariff negotiations and in the direction of tariff commitments that would arise from reciprocal North-South negotiations, if that is what the United States and other industrialized countries desire. Bagwell and Staiger (2014) describe this possibility in the context of the Doha Round. 
Bagwell, Kyle, and Robert W. Staiger (2016), "The Design of Trade Agreements," Chapter 8 in Bagwell and Staiger (eds) Handbook of Commercial Policy, Elsevier, December.

Bagwell, Kyle and Robert W. Staiger (2018a), "Multilateral Trade Bargaining and Dominant Strategies," International Economic Review, 59(4): 1785-1824.

Bagwell, Kyle, and Robert W. Staiger (2018b), National Sovereignty in an Interdependent World, in Lili Yan Ing and Miaojie Yu (eds.), World Trade Evolution: Growth, Productivity and Employment, Routledge, November.

Bagwell, Kyle, Robert W. Staiger and Ali Yurukoglu (2018), "Quantitative Analysis of Multi-Party Tariff Negotiations," mimeo.

Bagwell, Kyle, Robert W. Staiger and Ali Yurukoglu (2019), "Multilateral Trade Bargaining: A First Look at the GATT Bargaining Records," mimeo.

Bond, Eric W. and Jee-Hyeong Park (2002), "Gradualism in trade agreements with asymmetric countries," Review of Economic Studies 69: 379-406.

Curzon, Gerard (1966), Multilateral Commercial Diplomacy: The General Agreement on Tariffs and Trade and its Impact on National Commercial Policies and Techniques, Praeger: New York.

Devereux, Michael (1997), "Growth, Specialization, and Trade Liberalization," International Economic Review 38: 565-585.

Freund, Caroline L. and John McLaren (1999), "On the Dynamics of Trade Diversion: Evidence from Four Trade Blocs," Board of Governors of the Federal Reserve System International Finance Discussion Papers Number 637, June.

Furusawa, Taiji, and Edwin Lai (1997), "Adjustment Costs and Gradual Trade Liberalization," Journal of International Economics 49: 333-361.

Goldstein, Judith, and Joanne Gowa (2002), "U.S. national power and the post-war trading regime," World Trade Review, Volume 1, Issue 2, pp. 153-170.

Irwin, Douglas A., Mavroidis, Petros C. and Alan O. Sykes (2011), The Genesis of the GATT, Cambridge University Press.

Interim Commission for the ITO (1949), The Attack on Trade Barriers: A Progress Report on the Operation of the General Agreement on Tariffs and Trade. Geneva, August

Maggi, Giovanni (1999), "The Role of Multilateral Institutions in International Trade Cooperation," American Economic Review vol. 89, no. 1, March, pp. 190-214.

McLaren, John (1997), "Size, Sunk Costs, and Judge Bowker's Objection to Free Trade," American Economic Review, June, 87(3), pp. 400-20.

Posner, Eric A. and Alan O. Sykes (2014), "Voting rules in international organizations," Chicago Journal of International Law 15, 195.

Ross, Wilbur (2017), "Most Favored Nation Rule Hurts Importers, Limits U.S. Trade," The Wall Street Journal, Opinion, May 25. 
Schwartz, Warren F. and Alan O. Sykes (1997), "The Economics of the Most Favored Nation Clause," in Economic Dimensions in International Law: Comparative and Empirical Perspectives, edited by Jagdeep S. Bhandari and Alan O. Sykes, 43-79. Cambridge, UK: Cambridge University Press.

Staiger, Robert W. (1995), "A Theory of Gradual Trade Liberalization," in Deardorff, A., Levinsohn, J., and Stern, R. (eds.) New Directions in Trade Theory, University of Michigan Press.

Wallace, Benjamin B. (1933), "Tariff bargaining," Foreign Affairs, pp. 621-33.

Winters, Alan L. (1984), "British Imports of Manufactures and the Common Market," Oxford Economic Papers 36, pp. 103-118. 


\section{Figure 2. Hegemonic Transition: Equilibrium Payoffs}

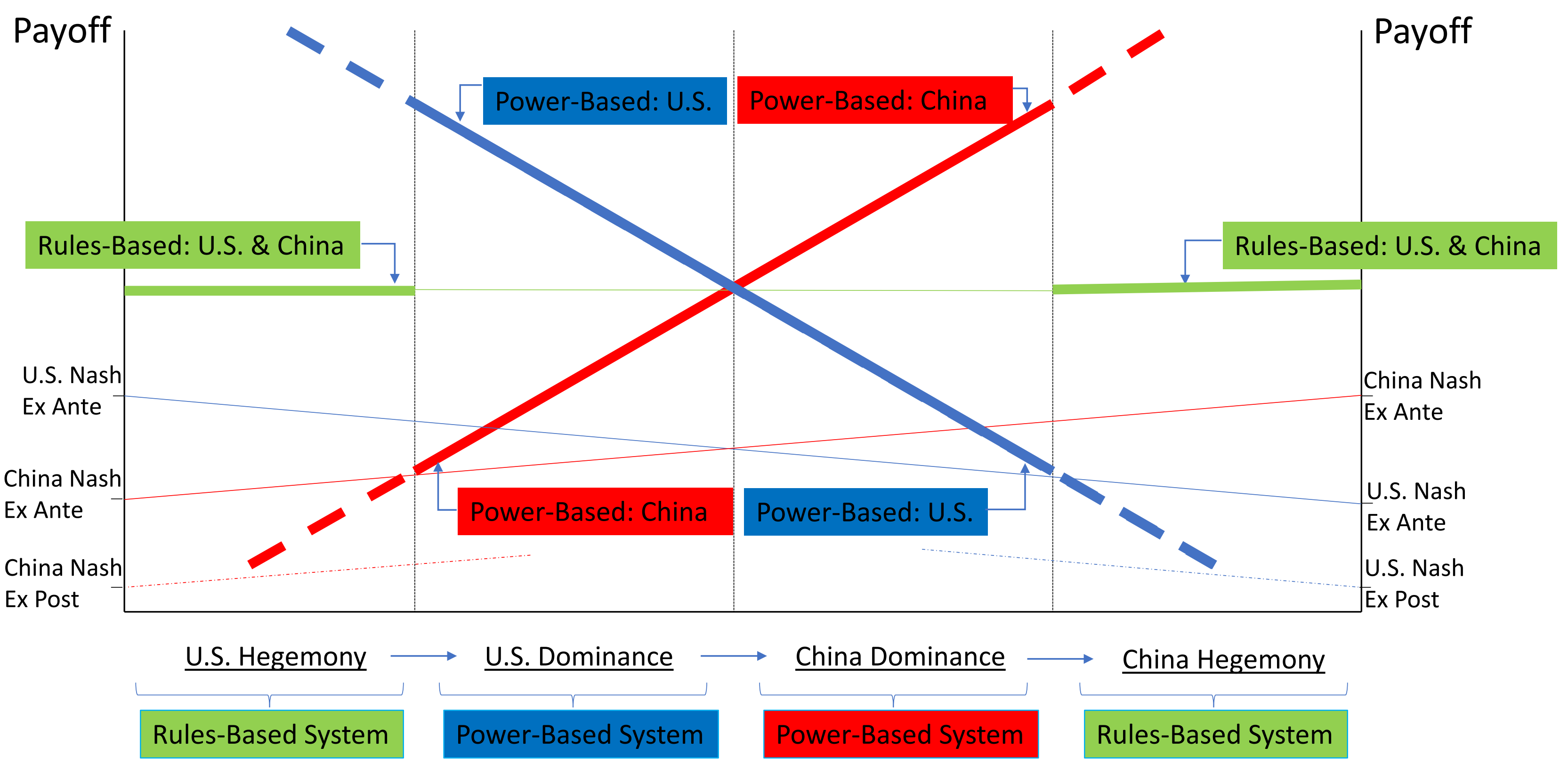




\section{Figure 3. Hegemonic Transition: Equilibrium Payoffs}

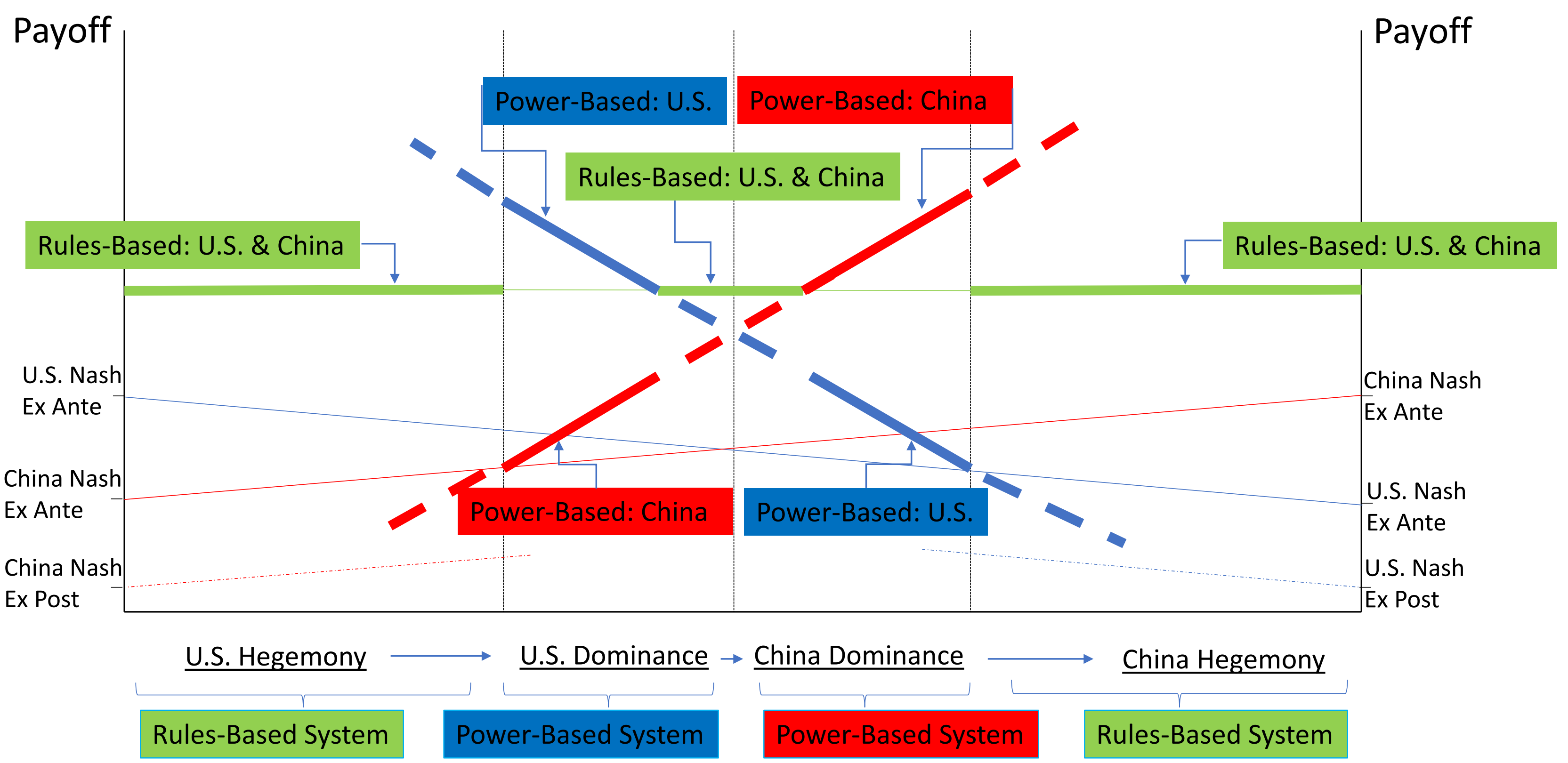

